\title{
VIOLENCE AND ROUGHNESS IN TRADITIONAL GAMES AND SPORTS: THE CASE OF FOLK FOOTBALL (ENGLAND AND SCOTLAND)
}

\author{
Laurent Sébastien Fournier
}

\begin{abstract}
The article addresses old English and Scottish annual village games known as folk football, which still survive along with the more usual federal modern sports like soccer and rugby. The article suggests that the example of folk football enables us to better understand the relationship between sport and violence. The use of the ethnographic method throughout a long-term period allows us to compare different existing games. The article describes aggressiveness in the games and its historical background. It also shows how the authorities tried to control and rule these traditional games. On the field, however, the players argue that the game is rough rather than violent. It is then important to pay attention to the players' viewpoint. Fieldwork on folk football matches shows that violence is drawn off at different levels. The case presented is an interesting one, grasping the relations between sport and violence. The violence that regularly appears in modern sport and hooliganism can be interpreted as an unconscious restoration of very old dual cultural schemes, connected in a broad psychological perspective to the youth's universal taste for pride and parade.
\end{abstract}

Keywords: ethnography, football, sport, tradition, United Kingdom, violence

In England and Scotland, some old annual village games known as folk football still survive along with the more usual federal modern sports like soccer and rugby. Technically, folk football matches feature huge scrums, in which two parts of a given village compete during several hours to bring the ball to the goal. At a social level, the games are typical for the relations they have with the traditional festivals, especially with Shrovetide and the wintertime festivals. Such games, and also their French historical equivalent known as la soule, have often been considered as extremely violent as they damage private property and enable personal revenge (Muchembled 1989). In this perspective, folk football has often been interpreted as a means of reaching catharsis: the traditional games that historically preceded institutionalised sports tended to be violent and acted as a security valve, allowing for some temporary freedom to people. 
On this basis, violence in sports has been historically and culturally legitimised. According to Norbert Elias and Eric Dunning (1986), for instance, the change from traditional games to modern sports follows a "civilising process", according to which modern sports feature a "controlled decontrolling of emotions". By contrast, traditional games such as folk football are typical for their violence and high level of free emotions. In this view, sociologists have often suggested that violence in modern sports is something like an archaism; the time when emotions are not under control anymore (Dunning \& Sheard 1979). From there, violence is often seen as the essence or the origin of sports, and many scholars have therefore focused on violence in sports, either on the field or among the spectators (Giulianotti et al. 1994; Carnibella et al. 1996; Bodin 2003). However, in recent years some social anthropologists have tried to understand the logic of such violence. It has been in particular suggested that violence in sports has more to do with participation in the match as a global social drama than with the sport itself (Bromberger 1995).

In this article I suggest that the example of folk football enables to understand better the relationship between sport and violence. At first sight, the folk football example shows that violence and sport are tightly linked, and even suggests that sport was born out of violence. But is this true? Studying folk football in Britain from the inside leads us to better understand the nature of violence in games and sports.

\section{METHODS}

In order to understand violence in folk football with the game's cultural logic, it was necessary to go beyond the usual statements from the media, almost all of which suggesting that this game is an especially violent one. For this purpose, I decided to use the ethnographic method within a long-term period and to compare different games. From 2006 to 2012, I attended annual folk football matches in seven places in Scotland (Kirkwall, Jedburgh, Ancrum, Duns, Lilliesleaf, Hobkirk, Denholm) and documented other games in four places in England (Ashbourne, Alnwick, Haxey, Workington). In all these different places I collected data on the history of the games and asked questions about violence and other aspects of games from the participants and spectators. In some cases (Kirkwall, Jedburgh, Ashbourne) I was introduced to the main protagonists of the games, including some key-players but also organisers and patrons. I usually stayed in these places for a few days to conduct some interviews with them. I also collected data from the archives of the School of Scottish Studies in Edinburgh, where the games have been documented for a long time as remarkable Scottish cultural practices. 
Concerning participation in the games, I soon realised that it would be impossible for me as a stranger to win a ball by myself. This is indeed reserved for players who have been involved in the games for many years. I could not even participate as a player because the players do not usually wear uniforms and so nobody could tell in which of the two teams I would be playing. However, I spent a long time hanging around the scrums, in the frost, sometimes until late in the night, waiting for the end of the game and discussing with both the players and the spectators. In the games with bigger scrums, in Kirkwall or Ashbourne, where several hundred people get involved, I often managed to jump on fences or on windows in order to get trapped in the game, above the scrum. For several minutes the scrum does not move and it is then possible to see the interactions between the players from very near. Such a position enables to observe the players and understand how they react when there is a sudden break or when the ball comes in their direction. Ethnography helps to understand the techniques and the strategies in the games. As a comprehensive method, it gives quite a different idea of the games than the one usually shown by the media.

\section{FOLK FOOTBALL: A VIOLENT GAME?}

Today, the folk football videos accessible online often show games which have nothing to do either with the official sport ideals or with fair-play. ${ }^{1}$ For instance, in Ashbourne's Royal Shrovetide Football, in Derbyshire, during a big scrum or mêlée in a river, the struggle for the ball is very rough. The players seem nervous and violence is everywhere; some of their heads are strongly knocked about. Some players lift up an opponent to prevent him from taking the ball and the latter answers with violence. Some other videos focus on the so-called ba'game in Kirkwall, Orkney. The images are even worse: some players in the mêlée are violently hit in the face. When somebody is considered to be too rude, the other players bring them to justice themselves. This way of settling quarrels is customary in the game and appears regularly in the same video ${ }^{2}$. In this town, one of the officials explains: " $B a$ ' is a very physical sport and people do get hurt. There have been numerous people with broken bones and black eyes". ${ }^{3}$ This aggressiveness on the playfield must be connected with a more symbolic violence. According to French sociologist Pierre Bourdieu, "symbolic violence" is related to cultural arbitrariness, which "manages to impose meanings and imposes them as legitimate while hiding the social relations that are behind them" (Bourdieu \& Passeron 1970). To put it in other words, symbolic violence lies in the domination of a person, group or society that imposes some ways 
of thinking and makes them look "normal" while making this domination unconscious for the dominated as well as for the dominants. Such domination can easily be found in folk football, which, similarly to every other game or sport, opposes the two teams of players in the hope for victory. The younger players are the first victims of symbolic violence: as the game is very popular among all children, one individual child cannot really choose if he wants to participate in the game or not. Moreover, this symbolic violence is also present within the children's teams and is not limited to the very day of the match: Lynne Fairgrieve ${ }^{4}$, living in Jedburgh, recalls a war between boys' clans, which lasted several weeks after the game. Billie Gillies ${ }^{5}$, a player in the same village, explains that until the $1960 \mathrm{~s}$, such segregation existed among adults as well. The two clans never met and used to go in their own pubs. Today, this is not the case anymore, but still occurs among children. Insisting on such a differentiation does not help to develop fair play or respect for the opposite team.

Lack of organisation adds to the violence of the game. In the little villages that practice folk football, like in Jedburgh or Ancrum, Roxburghshire, nobody cares for the traffic problems, or the casualties, or supervision of the annual encounters. Even if the traffic is limited in these two places, the scrum happening in the middle of the main street could be very dangerous if a car came a bit too fast or if the group of players suddenly broke loose. In the same way, the few "caution" advertisements hardly prevent the car drivers who usually end by driving erratically in the middle of the crowd.

\section{HISTORICAL ORIGINS}

The violence of folk football, however, is not surprising as it finds its origins in the violence of the traditional games before they were codified as sports. Thus, during the 18th century, several fights erupted in Scotland, and on the Islands of the Firth of Clyde, stone fights still regularly occur. Death was considered as normal during such practices, but they were not legally banned (Holt 1990). Moreover, fist fighting was codified in Scotland as a national championship due to aristocrats, pub owners and the customers of the Figg's Emporium boxing club, a place opened in 1719. However, in spite of this early fad, there were no rules in fist fighting until 1743, when Jack Broughton, who killed an opponent in a fight, decided to establish the first ones (ibid.). Another example is the one of fox hunting, which excited the players as if they were killing human beings during the war, according to Norbert Elias (Elias \& Dunning 1986). All these practices show well the violence and the dangers connected with physical activities, games and sports in the past. 
In such a context, folk football was also a game related to violence in the past. The dangers of folk football are easily perceptible if you know that one of the first rules in the Ashbourne game was to save the opponents' lives. ${ }^{6}$ You can wonder how this game took place to apply such rules. Then, it is interesting to recall the Scottish myth of folk football, collected in Jedburgh as well as in other places. According to some Scottish players, the ball represents the severed head of an English soldier, which again shows in which state of mind the ritual was performed. Moreover, the segregation between the teams until the $1960 \mathrm{~s}$, with each clan staying in their own parts of the town, was another form of violence. Folk football matches were a time when you had to prove to an unknown opponent that your own camp was able to hold the town.

Scottish historian John Burnett (2000) quotes a few verses from Walter Scott, who presents traditional football as a metaphor for war in the context of unceasing battles between Scotland and England:

Some drove the jolly bowl about;

With dice and draughts some chased the day;

And some, with many a merry shout,

In riot, revelry, and rout,

Pursued the football-play.

This poem shows that the traditional football matches were seen as huge noisy and illegal gatherings, very different from the other traditional games. Lastly, concerning the practice itself, playing with feet, aiming at a goal in the middle of the water, or cutting the ball into parts with a knife at the end of the game, increased the dangers of being wounded or drowned. ${ }^{7}$

\section{CONTROLLING AND RULING THE GAMES}

All these elements explain that the authorities always tried to control and rule these traditional games which caused much disorder because of their freedom and lack of organisation. Hugh Hornby, an English specialist in folk football, has summed up the different rules and trials against the games in his recent book (2008). The decrees and legal documents are the first evidence of the games. The word "football" appears for the first time in 1314 in a legal document found in London. Nevertheless, this document does not seem to have had much impact, as a few years later, in 1365, King Edward III had to ban the game again. While fighting against football games, the authorities of the time also tried to replace them by more useful activities. Various games had to be used to form skilful warriors in a context of permanent wars against Scotland or France: this is why archery should have been preferred to football. 
In Manchester, a few centuries later, people practicing football were fined. As some windows were broken for the "pleasure of the players", football was first forbidden in 1608. Ten years after, two officers were appointed to ensure that the law was obeyed: any player was fined 12 pence (ibid.).

Today, it is possible to find echoes of these historical legal critiques. Some local people, players or not, speak about their fears concerning the practice of folk football. According to Gavin Scott, a player in Jedburgh, it is dangerous to organise men's and boys' games on the same day. ${ }^{8}$ However, several young boys, sometimes less than 12 years old, do take part in their fathers' games. Given the violence of the actions in the scrum, especially when the game strikes the walls and the barricades, it is likely that a young boy being caught between the game and a house could be quite badly hurt and squashed. In Ancrum, a schoolteacher tried to stop the game because she found it too "barbarian". ${ }^{9}$ If you compare with a few centuries ago, people have become much more sensitive to violence. Whereas the first regulations tried to stop homicides during the matches, the actual claims only concern the risk of children being hurt. Norbert Elias and Eric Dunning (1986) explain this evolution through the "civilisation process", according to which people have become less and less violent and let the institutions regulate their private conflicts.

For other reasons, the shopkeepers in the places where the matches take place often emphasise the risks connected with folk football. On the days of the matches, the windows in the main streets are protected with barricades. This is necessary regarding the nature of the game, especially as the players can easily damage the windows with their shoulders. However, the real problem for the shopkeepers is the loss concerning the sales. In Jedburgh, a butcher explains that the ba' day is not a good day for his business because the sales decline considerably. In another street, a jeweller explains that the game does not disturb her, but that she usually uses this day to draw up an inventory in order not to lose a day. In the same street, another shop prefers to take a day off. On the days of football games, anyway, a significant part of the population do not dare to come downtown at the risk of being knocked down by the group of players.

The practice of folk football, like all the free traditional games, is also a problem for the public order. Indeed, these games still sometimes need police intervention. This was, for instance, the case in Jedburgh, during the 2005 game, when the police had to arrest one of the players who had been denounced as being violent with other players in the scrum. Of course, such outbursts are difficult to avoid, because even if most of the people want to promote respect and fair play, there are always some individuals who come for a fight and go crazy in a game without any formal and accepted standards. Furthermore, problems 
concerning public liability and damage done to private property have often been raised, together with the traffic problems, to ban the games. ${ }^{10}$

In these conditions the town councils have often become reluctant to continue the games. As nobody is legally responsible, it is the town that has to repair the damage or take responsibility for the injured people. This topic has been discussed in Kirkwall where some officials have asked to stop giving public subsidies to folk football. Indeed, each year the local town council pays for the damage, repairing doors and windows of private houses, for instance when a whole wall was pushed down by the pressure from the scrum. Nevertheless, the most important threat here is connected with the risk of a player or an onlooker being injured because of the game. People go to court more and more frequently, attacking the public institutions which support the games, in order to get some financial compensation for the injuries caused by the games.

\section{IN THE PLAYERS' VIEW}

On the field, however, the players argue that the game is rough rather than violent. Hugh Hornby (2008), convinced that folk football is part of the British cultural heritage, protects the games from the danger of becoming too much organised. According to him, the world of folk football can survive only if it is not trapped in liability problems and if it manages to escape the "health and security" issues. Otherwise it could quickly be overwhelmed by a whole set of regulations which would lead to its disappearance.

Furthermore, there are no statistics proving that these practices would cause more injuries than the modern sports. While scrutinising the figures, Hornby (2008) counted only 9 dead players in folk football matches since 1800. Five were drowned, two had a heart attack, one died because of hypothermia and the last one was impaled on a fence. This is considerably fewer than in modern sports, especially as compared with American football, in which 33 players died only in 1908. In Jedburgh, a group of ten-year-old boys said that they had never heard about folk football accidents in this town and only remembered a player having been struck by a car two years before. Still in Jedburgh, the same year, a confirmed player presented the idea of respect and explained during an interview: "I have been doing it since I was a child. There are no rules, old people play and young people have respect for them. It is just common sense"11. Mixing different ages seems a good means to prevent the outbursts, with the older players steering the younger ones. G. Linbin, a long-term player at Hobkirk, a village near Jedburgh, explains this harmony in the game. According to him, people often practise for a long time, even after 70 years old, because this an- 
nual event is their favourite sports activity. It is part of the local social life and almost everybody takes part in it. During the game, people play as much with the ball as with the other people, joking with them as well as trying to provoke them. There are no injuries because the Jedburgh version of the game is very quiet, which enables any suffering player in the scrum to cry out in order to stop the game for a while. ${ }^{12} \mathrm{H}$. Hornby (2008) maintains that violence in folk football is similar to that in any other sport, and that it almost never occurs at the end of the matches. Folk football is more related to pleasure and camaraderie. Anybody trying to escape this spirit of the game is rejected by the group.

In the different places where folk football is practised, the game seems to be very little organised: once the ball is in the scrum, everybody tries to grasp it without minding the other players or using any elaborate technique. Only some occasional actions prove that it is a collective game. Nevertheless, suddenly the game stops and everybody moves aside. The ball is thrown up again and the game begins anew. We learn further on that this unwritten rule applies when a player is in a too difficult position inside the scrum. This rule originates from professional sport, namely rugby. There are very few written rules, which contribute to the game's success. To learn the rules, there is no need to look for them in any official document: it is better to participate, to observe and ask questions. This is what the younger people do during their first matches, trying to imitate the older. They learn to respect their opponents without the help of a referee, and they learn not to trespass into the gardens, private houses, around the churches, railway tracks and main roads. Holt (1990) goes further when he explains that fair play and respect for standards are key features in amateur practices, and that they have been endangered by professionalism in sports from the beginning of the 20th century onwards. This perspective may be idealistic but it nevertheless shows that traditional games knew how to impose respect for the others as well as for the environment during the game, which has not always been the case in modern sports.

\section{SELF-REGULATION OF THE OUTBURSTS}

In the folk football matches, people take care of the children and try to prevent the outbursts. R. Leslie, in Kirkwall, explains that the boys' game is limited between the ages of 7 and 16. During the match, the boys' fathers are around the scrum to regulate the game. In Jedburgh, the boys' game is supervised in a similar way. An older player is there to get out of the scrum any player whose behaviour could be harmful and reminds him: "Play the ba' and not the man." Concerning security issues, special signboards are mounted, which signal the 
cars to go slow. The police are sometimes there, but usually keep a distant eye on the game. To protect the houses and shops nearby, barricades are built up to protect the windows of dwellings and shops, which may be damaged during the game. In Ashbourne and Kirkwall, joiners and glaziers form a committee among the players and repair the damages if necessary, after the match, to prevent the owners from calling their insurance companies or making the repairs themselves. Sometimes, money is collected to finance such reparations. Concerning the general organisation of the games, the local committees launch special events before the matches and raise funds, either to have the balls made or to serve some charitable purposes. Moreover, there is an organisation on a national scale with a special calendar devoted to folk football games all over Britain. ${ }^{13}$

Not only are the games regulated in such an informal way, but their rules also continually change to fulfil the requirements of the modern society and its new standards. In Jedburgh the game changed from football using the feet to hand-played handball. The first rule had already been formulated, prohibiting to strike above the feet, due to broken legs, but this was not enough and was followed by the transformation of football into handball. Moreover, the few cases of drowning often led to changes in the position of the goals, which in the past used to be in the middle of rivers. ${ }^{14}$ Therefore, dozens of players had to fight for the ball in a very risky environment. Even if in some places the game is still played in the water, changing the position of the goals has limited the number of accidents. Concerning more precise regulations, some other examples show that the games can transform and adapt to modernity: Ashbourne, for instance, prohibited the use of motor engines for carrying the ball and ordered games to be finished at $10 \mathrm{pm}$ instead of midnight in order to make the policemen's work easier. In spite of their traditional aspects, the games demonstrate their ability to change, in order to become less risky. Nowadays, some places where no such regulations yet exist think about introducing them. However, some players feel that the games could be under threat, explaining that too much regulation would spoil their pleasure.

\section{UNDERSTANDING OF VIOLENCE TO CONTROL IT BETTER}

Fieldwork on folk football matches thus shows that violence is eliminated at different levels: the fear to see the game being banned in the next years, the fact that everybody knows each other in the game, and the presence of women and children among the spectators has led the players to a lot of self-control in spite of the roughness of the play. Likewise, the promotion and organisation 
of the games are carefully regulated to avoid criticism and fears inspired by the old catharsis theory. Although the practice of folk football is considered to be violent, its performers try to create a positive image for it in order for it not to be condemned. Thus, even if we suppose that determination to maintain the games limits their violence in the present time, it seems possible to imagine that they were not as violent in the past as the historians would say. This shift between the violence of folk football in historical discourses and the lack of violence on the field today leads to several general questions. Does the presentation of a game as violent paradoxically lead to limiting or taming its violence on the field? In other words, is it possible to prevent violence through ritualisation or mythification? And, the other way round, can the high level of regulation in modern sports be analysed as a means of frustration which could indirectly encourage violence, either within the game or outside it?

The data presented here eventually enable us to provide new elements to understand the difficult relations between modern sports and violence. The folk football example, indeed, shows that violence is almost as old as sport itself, and that they have always been connected. In the catharsis theory, the temporary violence allowed by the game paradoxically leads to the renewal and reinforcement of the established order. In European traditional societies, violence occurs in a ritual way at the end of the winter, coming along with the renewal of nature itself. According to cultural anthropologists, games and ritual contests in this season symbolically marked the end of the old year and the beginning of the new one. The British folk football, like the French game of la soule or the Russian Maslenitsa games, was connected with the underlying beliefs which associated the victory of a given team and the prophecy to harvest good crops in the next year. These contests traditionally opposed married men and bachelors in the villages, which symbolised the old and the new year respectively. Ritually organised during the time of the Carnival, more or less encouraged by the clergy and the local nobility, the games were set for the opening of the new year, which until the 16th century coincided with the beginning of Easter. Like in the African "ritual wars" (Gluckman 1963) or in the "flourished war" of the Aztecs (Duverger 1978), the European traditional rural societies performed during their games some fundamental symbolic oppositions between ritual moieties featuring the old and the new, the winter and the summer, the cold season and the hot season, the time of the individual and the time of the collective, and even the evil and the good.

The violence that regularly appears in modern sport and hooliganism can therefore be interpreted as an unconscious restoration of these very old dual cultural schemes, connected in a broad psychological perspective to the youth's universal taste for pride and parade (Muchembled 1989). Deeply anchored in 
the cultural logic of "ludic inversion" (Bakhtine 1970), according to which what is usually forbidden by a given society is exceptionally allowed during its festivals and games, this specific sort of violence needs to be culturally understood rather than really fought against. Without trying to find any excuses for this violence, nor diminishing its danger in a modern society based on rationality and order, it seems better to remember its logic rather to simply condemn it. It is then important to regard it as a means to ritualise dual oppositions within a group, i.e., as an ancestral scheme that manages to last through sport in a new context. Unlike mass violence in wars or free violence in crimes, sport violence can be drawn off and better regulated if we manage to remind ourselves clearly enough that its logic is not serious but has something to do with the game's logic.

\section{NOTES}

1 Ashbourne Royal Shrovetide Football: Ash Wednesday 2008, http://uk.youtube.com/ watch?v=cvkCcCXweOo, last accessed on June 7, 2013.

${ }^{2}$ Kirkwall ba' 2007, http://uk.youtube.com/watch?v=S5_YTSQpIuE, last accessed on June 7, 2013.

3 BBC News: Ba' game legal threat fears, May 9, 2001, http://news.bbc.co.uk/1/hi/ scotland/1320785.stm, last accessed on June 7, 2013.

${ }^{4}$ Document SA 2006-014, Sound Archives, School of Scottish Studies, University of Edinburgh.

5 Ibid.

6 BBC Derby: Ashbourne Shrovetide Football, The Rules of Shrovetide Football, February 6, 2006, http://www.bbc.co.uk/derby/content/articles/2006/02/06/ashbourne_ shrovetide_football_rules_feature.shtml, last accessed on June 7, 2013.

7 Document UD 9 Jethart Ba', Sound Archives, School of Scottish Studies, University of Edinburgh.

8 Document SA 2006-014, Sound Archives, School of Scottish Studies, University of Edinburgh.

9 Document VA 2000-06, Sound Archives, School of Scottish Studies, University of Edinburgh.

${ }^{10}$ BBC News: Streets full for ba' game battles, 15 February 2008, http://news.bbc.co.uk/1/ hi/scotland/south_of_scotland/7246475.stm, last accessed on June 7, 2013.

${ }^{11}$ Interview conducted in Jedburgh, March 9, 2006.

12 Document SA 1989-096, Sound Archives, School of Scottish Studies, University of Edinburgh. 
${ }^{13}$ Calendar available on website http://www.playedinbritain.co.uk/books/uppies-anddownies.php, last accessed on June 7, 2013.

${ }^{14}$ Document UD 9 Jethart Ba', Sound Archives, School of Scottish Studies, University of Edinburgh.

\section{MANUSCRIPT SOURCES}

Interviews and field notes from Scotland and England in the possession of the author: Kirkwall (2006, 2007), Jedburgh (2008, 2012), Ancrum (2008, 2012), Duns (2008), Lilliesleaf (2008), Hobkirk (2008), Denholm (2012), Ashbourne (2009, 2012), Alnwick (2009), Haxey (2012), Workington (2010).

\section{REFERENCES}

Bakhtine, Mihail 1970. L'œuvre de François Rabelais et la culture populaire au MoyenAge et sous la Renaissance. Paris: Gallimard.

Bodin, Dominique 2003. Le hooliganisme, Paris: Presses Universitaires de France.

Bourdieu, Pierre \& Passeron, Jean-Claude 1970. La reproduction. Eléments pour une théorie du système d'enseignement, Paris: Editions de Minuit.

Bromberger, Christian 1995. Le Match de football. Paris: Maison des Sciences de l'Homme.

Burnett, John 2000. Riot, Revelry, and Rout: Sport in Lowland Scotland before 1860. East Linton: Tuckwell Press.

Carnibella, Giovanni \& Fox, Anne \& Fox, Kate \& McCann, Joe \& Marsh, James \& Marsh, Peter 1996. Football violence in Europe: a report to the Amsterdam Group. Oxford: The Social Issues Research Centre. http://www.sirc.org/publik/football_violence. pdf, last accessed on June 6, 2013.

Dunning, Eric \& Sheard, Kenneth 1979. Barbarians, Gentlemen and Players: A Sociological Study of the Development of Rugby Football. Oxford: Martin Robertson.

Duverger, Christian 1978. L'esprit du jeu chez les Aztèques. Mouton \& Paris \& La Haye: EHESS.

Elias, Norbert \& Dunning, Eric 1986. Sport et civilisation. La violence maîtrisée. Paris: Fayard.

Giulianotti, Richard \& Bonney, Norman \& Hepworth, Mike (eds.) 1994. Football, Violence and Social Identity. London \& New York: Routledge.

Gluckman, Max 1963. Order and Rebellion in Tribal Africa. New York: The Free Press of Glencoe.

Holt, Richard 1990. Sport and the British. A Modern History. Oxford: Clarendon Press.

Hornby, Hugh 2008. Uppies and Downies. The Extraordinary Football Games of Britain. Swindon: English Heritage.

Muchembled, Robert 1989. La violence au village (XVe-XVIIe siècles). Bruxelles: Brépols. 